
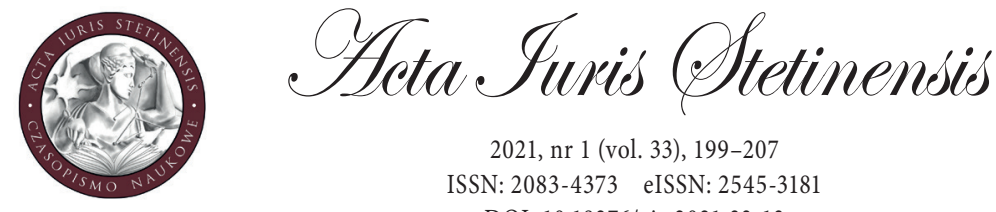

2021, nr 1 (vol. 33), 199-207

ISSN: 2083-4373 eISSN: 2545-3181

DOI: $10.18276 /$ ais.2021.33-13
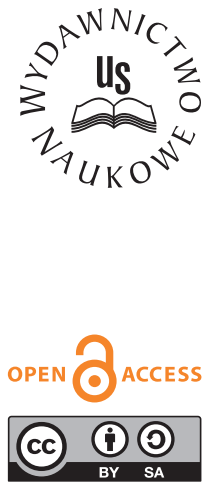

\title{
Wyrok Wojewódzkiego Sądu Administracyjnego w Szczecinie z dnia 10 grudnia 2020 r., II SA/Sz 453/20
}

1. Obecne brzmienie art. 2 pkt 2 lit. a ustawy z dnia 31 maja o osobach deportowanych do pracy przymusowej oraz osadzonych w obozach pracy przez III Rzeszę i Związek Socjalistycznych Republik Radzieckich (tj. z dnia 6 czerwca 2019 r., Dz.U. z 2019 r. poz. 1168) nie wprowadza kryterium geograficznego, czy też, inaczej mówiąc, kryterium odległości na jaką miało nastąpić wywiezienie, jako warunku przyznania świadczenia pieniężnego z tytułu deportacji do pracy przymusowej.

2. Dla przyznania rzeczonego świadczenia konieczne jest ustalenie, że w konkretnym przypadku miała miejsce deportacja, czyli wywiezienie do pracy przymusowej na okres co najmniej 6 miesięcy w granicach terytorium państwa polskiego sprzed dnia 1 września 1939 r., oraz że strona świadczyła pracę pod przymusem na rzecz okupanta. Przy czym deportacja musiała łączyć się z przymusowym wywiezieniem, wyrwaniem i odizolowaniem od dotychczasowego środowiska, a następnie życiem w otoczeniu wrogości i wyobcowania.

3. Dla ustalenia istnienia przesłanki deportacji istotne są wszystkie okoliczności sprawy, które w stanie faktycznym konkretnej sprawy mogą przesądzić o uznaniu za deportację również wywiezienia do pracy przymusowej do miejscowości położonej w niewielkiej odległości od dotychczasowego miejsca zamieszkania. W tym też kontekście istotne jest zatem ustalenie nie tylko samej odległości od dotychczasowego miejsca zamieszkania do miejscowości, do której dana osoba została wywieziona, ale również, gdzie przebywała jej najbliższa rodzina, czy mogła się z nią kontaktować, w jakich warunkach żyła po wywiezieniu do pracy 
przymusowej, jakiego rodzaju pracę wykonywała, jakie było wobec niej nastawienie nowego otoczenia. Wszystkie te czynniki łącznie mogą bowiem w okolicznościach konkretnej sprawy przesądzić o zaistnieniu przesłanki deportacji w przedstawionym wyżej rozumieniu.

Przewodniczący: Sędzia WSA Patrycja Joanna Suwaj (spr.)

Sędziowie WSA: Renata Bukowiecka-Kleczaj, Katarzyna Grzegorczyk-Meder

Wojewódzki Sąd Administracyjny w Szczecinie po rozpoznaniu na posiedzeniu niejawnym w dniu 10 grudnia 2020 r. sprawy ze skargi C.K. na decyzję Szefa Urzędu do Spraw Kombatantów i Osób Represjonowanych w W. z dnia [...] r. nr [...] w przedmiocie przyznania świadczenia pieniężnego I. uchyla zaskarżoną decyzję i poprzedzającą ją decyzję Szefa Urzędu do Spraw Kombatantów i Osób represjonowanych z dnia [...]. nr [...], II. zasądza od Szefa Urzędu do Spraw Kombatantów i Osób Represjonowanych w W. na rzecz skarżącego C.K. kwotę [...]([...]) złotych tytułem zwrotu kosztów postępowania.

\section{Uzasadnienie}

1. Wnioskiem z dnia 12 listopada 2019 r. C.K. (dalej przywoływany jako: „Skarżący”), zwrócił się z prośbą o „odszkodowanie za czasy okupacji”. We wniosku wskazał, że jako 12-letnie dziecko został skierowany do pracy przymusowej - „wywieziony na okopy", 16 kilometrów od domu, gdzie był zmuszony do pracy do późnego wieczora.

2. Szef Urzędu do Spraw Kombatantów i Osób Represjonowanych, po rozpoznaniu wniosku, decyzją z dnia [...] stycznia 2020 r. odmówił Skarżącemu przyznania uprawnienia do świadczenia pieniężnego z tytułu pracy przymusowej.

W uzasadnieniu Organ krótko wskazał, że z opisu represji przedstawionego przez Skarżącego wynika, że praca przymusowa nie była połączona $\mathrm{z}$ wywiezieniem (deportacją) a Skarżący codziennie dochodził do pracy z rodzinnego domu.

3. We wniosku o ponowne rozpatrzenie sprawy Skarżący wskazał na nieścisłości w opisie sytuacji. Uwypuklił, że faktycznie miała miejsce deportacja, gdyż Skarżący wspólnie z innymi został przewieziony z miejsca zamieszkania do miejsca obozu pracy, że za przewinienia groził brak przepustki do domu, wywóz do innych obozów lub śmierć. Wskazał, że przepustki były ,jakby przejściem do stołówki po żywność", zaś dotkliwe kary skutkowały pracą o głodzie; w przypadku Skarżącego zastosowana kara - dotkliwe pobicie skutkowała utratą wzroku w lewym oku.

4. Po ponownym rozpatrzeniu sprawy Szef Urzędu do Spraw Kombatantów i Osób Represjonowanych, decyzją z dnia [...] marca 2020 r., utrzymał ww. decyzję w mocy, wskazując w uzasadnieniu decyzji, że praca Skarżącego wprawdzie mogła 
mieć charakter pracy przymusowej, ale trudno ją uznać za wykonywaną w warunkach deportacji, gdyż Skarżący dochodził do pracy z rodzinnego domu. Organ poprzestał na dotychczasowych dowodach uznając, że zeznania świadka nie mogą mieć znaczenia dla rozstrzygnięcia sprawy.

5. W skardze na powyższą decyzję Skarżący zarzucił obu rozstrzygnięciom błędne zastosowanie art. 1a ust. $1 \mathrm{i}$ art. 2 ustawy z dnia 31 maja o osobach deportowanych do pracy przymusowej oraz osadzonych w obozach pracy przez III Rzeszę i Związek Socjalistycznych Republik Radzieckich.

W uzasadnieniu skargi wskazał, że jako dziecko 12-letnie został wyrwany z dotychczasowego życia rodzinnego i zmuszony do pracy na rzecz okupanta w miejscowości W. położonej $16 \mathrm{~km}$ od domu rodzinnego. Pracę wykonywał przez okres 9 miesięcy. Skarżący uwypuklił, że wprawdzie wracał wieczorem do domu, ale nie miał nawet siły na rozmowę z rodzicami; wracał tylko po to, żeby przenocować i że nie miał czasu na życie rodzinne z rodzicami. Wskazał, że był dzieckiem, a był zmuszony do pracy jak dorosły, ponad siły, bez jedzenia, bez picia, bez możliwości mycia czy toalety. Pracował jak niewolnik, był odizolowany od dotychczasowego środowiska, nie miał możliwości spotykania się z rówieśnikami.

6. W odpowiedzi na skargę Szef Urzędu do Spraw Kombatantów i Osób Represjonowanych wniósł o jej oddalenie, podtrzymując dotychczasową argumentację oraz stanowisko zawarte w uzasadnieniu zaskarżonej decyzji.

Wojewódzki Sąd Administracyjny w Szczecinie, zważył, co następuje:

7. Skarga jest zasadna i podlega uwzględnieniu.

8. Na wstępie wywodu należy nakreślić ramy prawne sprawy.

Zgodnie $\mathrm{z}$ art. 2 ustawy z dnia 31 maja o osobach deportowanych do pracy przymusowej oraz osadzonych w obozach pracy przez III Rzeszę i Związek Socjalistycznych Republik Radzieckich (tj. z dnia 6 czerwca 2019 r., Dz.U. z 2019 r. poz. 1168) represją $\mathrm{w}$ rozumieniu ustawy jest: 1) osadzenie w obozach pracy przymusowej w okresie wojny w latach 1939-1945 z przyczyn politycznych, narodowościowych, rasowych i religijnych; 2) deportacja (wywiezienie) do pracy przymusowej na okres co najmniej 6 miesięcy w granicach terytorium państwa polskiego sprzed dnia 1 września $1939 \mathrm{r}$. lub z tego terytorium na terytorium: a) III Rzeszy i terenów przez nią okupowanych w okresie wojny w latach 1939-1945,

9. W ocenie Sądu błędny jest pogląd Szefa Urzędu, że w przypadku Skarżącego nie został spełniony warunek deportacji (wywiezienia) do pracy przymusowej tylko dlatego, iż świadczył on pracę przymusową w pobliżu miejsca stałego zamieszkania $\mathrm{i}$,dochodził do pracy z rodzinnego domu”.

Wbrew twierdzeniom zawartym w uzasadnieniu zaskarżonej decyzji, z których mogłoby wynikać, że Organ wziął pod uwagę treść uzasadnienia wyroku Trybunału 
Konstytucyjnego z dnia 19 grudnia 2009 r., sygn. akt K 49/07 (OTK-A 2009/11/169), Organ rozpatrzył sprawę w istocie na podstawie kryterium geograficznego, którego stosowanie $\mathrm{w}$ sprawach dotyczących świadczenia pieniężnego z tytułu deportacji do pracy przymusowej Trybunał wykluczył jako niezgodne z Konstytucją RP. Podkreślić należy, że z dniem 20 kwietnia 2011 r. art. 2 pkt 2 zdanie wstępne ustawy uległ zmianie (na skutek ww. wyroku Trybunału Konstytucyjnego) w ten sposób, że wyeliminowano $\mathrm{z}$ tego przepisu ograniczenie pojęcia deportacji wyłącznie do wywiezienia $\mathrm{z}$ terytorium państwa polskiego, $\mathrm{w}$ jego granicach sprzed dnia 1 września 1939 r., rozszerzając to pojęcie na wywiezienie również w granicach terytorium państwa polskiego sprzed dnia 1 września 1939 r. W decyzji swej Organ wykazywał, że Skarżącego skierowano do pracy przymusowej w miejscowości oddalonej o 16 kilometrów od miejsca zamieszkania, oraz, że do pracy „dochodził”, co skutkowało ustaleniem, że w przypadku Skarżącego nie nastąpiło wywiezienie.

Z uzasadnienia zaskarżonej w tej sprawie decyzji wynika, że Organ skupił się jedynie na okoliczności wykonywania przez Skarżącego pracy przymusowej w miejscowości sąsiedniej w stosunku do jego miejsca zamieszkania. Koronny argument Organu stanowil fakt „dochodzenia do miejsca pracy” przez Skarżącego.

Organ niewątpliwie nadal nie dostrzega, że obecne brzmienie art. 2 pkt 2 lit. a ustawy nie wprowadza kryterium geograficznego, czy też, inaczej mówiąc, kryterium odległości na jaką miało nastąpić wywiezienie, jako warunku przyznania świadczenia pieniężnego z tytułu deportacji do pracy przymusowej. Dla przyznania rzeczonego świadczenia konieczne jest ustalenie, że w konkretnym przypadku miała miejsce deportacja, czyli wywiezienie do pracy przymusowej na okres co najmniej 6 miesięcy w granicach terytorium państwa polskiego sprzed dnia 1 września 1939 r., oraz że strona świadczyła pracę pod przymusem na rzecz okupanta. Przy czym deportacja musiała łączyć się z przymusowym wywiezieniem, wyrwaniem i odizolowaniem od dotychczasowego środowiska, a następnie życiem w otoczeniu wrogości i wyobcowania. Natomiast sam fakt odległości wywiezienia nie został poddany reglamentacji prawnej, tym samym nieuprawnione jest obwarowywanie tej przesłanki dodatkowymi, pozaustawowymi warunkami. Odmienne rozumienie tego przepisu, polegające na braniu pod uwagę opisanego wyżej kryterium geograficznego za decydujące, stanowi naruszenie przepisu prawa materialnego, polegające na jego błędnej wykładni.

Szef Urzędu ponownie stwierdził, że w przypadku Skarżącego nie został spełniony warunek deportacji (wywiezienia) do pracy przymusowej, z uwagi na niewielką odległość miejsca wykonywanej pracy od miejsca dotychczasowego zamieszkania oraz fakt „dochodzenia” przez Skarżącego do miejsca pracy z domu rodzinnego. 
10. Skoro materiał dowodowy, zgromadzony w przedmiotowym postępowaniu to jedynie trzy pisma Skarżącego (Organ mimo wniosku Skarżącego o przesłuchanie świadka nie przeprowadził takiego dowodu), z których jednak wynika jednoznacznie, że w okresie od kwietnia do grudnia 1944 roku, czyli przez 9 miesięcy Skarżący, wywieziony do pobliskiej miejscowości W., pracował przymusowo przy budowie niemieckich bunkrów i okopów, bezspornie też został wbrew własnej woli, a więc przymusowo, wywieziony ze swojego dotychczasowego miejsca zamieszkania, a jak wskazywał Skarżący, do domu wracał tylko na noc i odbywało się to w trybie przepustki (nagrody), to Organ winien rozważyć weryfikację swych dotychczasowych ustaleń (zawartych w decyzji z dnia [...] stycznia 2020 r. oraz z dnia [...] marca 2020 r.) o niespełnieniu, w przypadku Skarżącego przesłanki deportacji w świetle powołanej wyżej wykładni art. 2 pkt 2 lit. a ustawy.

Dodatkowo podnieść należy, że przy wykładni znowelizowanego przepisu art. 2 pkt 2 ustawy należy pamiętać, że nie może ona zmierzać do ograniczenia dostępności do tego świadczenia. Celem nowelizacji było zrównanie uprawnień osób wywiezionych do pracy przymusowej poza granice kraju $\mathrm{z}$ wywiezionymi $\mathrm{w}$ granicach terytorium państwa polskiego sprzed dnia 1 września 1939 r. Taką wykładnię też prezentuje się w orzeczeniach sądów administracyjnych. Kwestia odległości miejsca, do którego deportowano (wywieziono) Skarżącego od miejsca jego stałego zamieszkania, jest jedynie jednym z czynników wskazujących na zaostrzony charakter represji i podlega ocenie organu przy uwzględnieniu wszystkich innych okoliczności sprawy. Nie można zatem z góry wykluczyć sytuacji, w której strona była deportowana $\mathrm{w}$ rozumieniu ustawy, mimo iż znajdowała się $\mathrm{w}$ niedalekim oddaleniu od dotychczasowego miejsca zamieszkania (por. wyrok Naczelnego Sądu Administracyjnego z dnia 13 września 2012 r., sygn. akt II OSK 227/12).

Sąd orzekający w sprawie $\mathrm{w}$ pełni podziela ugruntowane dotąd stanowisko sądów administracyjnych, że deportacja w świetle powołanego przepisu i przy uwzględnieniu stanowiska Trybunału Konstytucyjnego, stanowiła szczególnie dotkliwą formę represji, która musiała się łączyć z przymusowym wywiezieniem, „wyrwaniem” i odizolowaniem od dotychczasowego środowiska. Było to zwłaszcza uciążliwe w odniesieniu do osób bardzo młodych lub w podeszłym wieku, których zdolności do samodzielnej egzystencji w nowym miejscu były znacznie ograniczone. Następowało to zaś kosztem znacznego pogorszenia warunków życiowych, w stosunku do warunków, istniejących w dotychczasowym miejscu pobytu lub zamieszkania. Jak zaznaczył też Trybunał Konstytucyjny, wywożeni do pracy przymusowej byli przed wszystkim ludzie młodzi. Nie obojętne były też warunki, w których osoby wywiezione musiały funkcjonować w miejscu deportacji oraz konieczność organizowania codziennego życia od podstaw. Jednak decydującym, w takim przypadku, był brak możliwości utrzymania dotychczasowych 
więzi rodzinnych, przyjacielskich i sąsiedzkich. Istotnym zatem będzie ustalenie czy osoba deportowana mogła odwiedzać dom rodzinny, znajomych oraz przyjaciół i czy mogła kontynuować istniejące więzi rodzinne i społeczne - gdzie było jej rzeczywiste centrum życiowe. Deportacja wiązała się też niewątpliwie z życiem w otoczeniu wrogości, brakiem więzi społecznych, wyobcowaniem kulturowym i językowym, co dodatkowo pogłębiało charakter tej represji (por. np. wyrok Wojewódzkiego Sądu Administracyjnego w Gdańsku z dnia 10 kwietnia 2013 r., sygn. akt II SA/Gd 786/12; wyrok Naczelnego Sądu Administracyjnego z dnia 18 lutego 2015 r., sygn. akt II OSK 1722/13).

W związku z powyższym wywiezienie, jak w przypadku Skarżącego, do sąsiedniej miejscowości (rzeczywista odległość nie ma w przedmiotowej sprawie decydującego znaczenia), jeżeli trwało co najmniej 6 miesięcy i było związane $\mathrm{z}$ wykonywaniem pracy przymusowej wypełnia ustawowe przesłanki uprawniające do świadczenia pieniężnego.

Nie zmieniają tego faktu twierdzenia Organu, stanowiące błędną interpretację oświadczeń Skarżącego, składanych w toku postępowania. Okoliczność, że Skarżący - wówczas 12-letnie dziecko, jak wskazał Organ „dochodził” do pracy i po pracy wracał do domu, nie stanowi o złagodzeniu represji, a raczej o braku wnikliwego przeanalizowania indywidualnej sytuacji Skarżącego. Nie można bowiem z tego rodzaju okoliczności wyprowadzać wniosku o utrzymywaniu przez Skarżącego więzi rodzinnych. Wskazywanie na wyrwane z kontekstu złożonych przez Skarżącego oświadczeń, że wracał on do domu rodzinnego, w świetle ustaleń w zakresie wieku dziecka, całodniowym braku jedzenia i picia, stosowanych kar, braku w istocie więzi rodzinnych i społecznych, odległości, jaką dziennie (przed i po pracy) musiało pokonywać dziecko, poddane następnie nadludzkiemu wysiłkowi przy pracy, stanowi nieprawidłową ocenę zgromadzonego w sprawie materiału dowodowego. Tym bardziej, że była to jak na chłopca praca ciężka, bez możliwości jedzenia, picia czy toalety. Organ nie rozważył oświadczenia Skarżącego, że powrót do domu stanowił przepustkę/nagrodę i dawał jedyną możliwość spożycia posiłku.

Powyższe ustalenia, nie mogły zostać uznane za oparte na prawidłowej ocenie całokształtu materiału dowodowego. W ocenie Sądu Organ nie poczynił ustaleń pozwalających na udzielenie odpowiedzi, czy poza odległością od miejsca zamieszkania i dochodzenia do pracy, w przypadku Skarżącego zachodziły inne okoliczności, wskazujące na fakt deportacji. Z uzasadnienia zaskarżonej decyzji, ani decyzji jej poprzedzającej, nie wynika, na podstawie jakich okoliczności oraz dowodów organ uznał, że Skarżący nie został deportowany, tj. „wyrwany” ze swojego dotychczasowego środowiska. Organ w uzasadnieniu decyzji w istocie ograniczył się do stwierdzenia, że Wnioskodawca został skierowany do pracy w miejscowości 
sąsiedniej w stosunku do miejsca stałego zamieszkania, do pracy dochodził, a więc nie nastąpiło odizolowanie od środowiska.

11. Zdaniem Sądu ani wykonywanie pracy przymusowej w miejscowości położonej w niewielkiej odległości od miejsca zamieszkania ani nawet, jak w okolicznościach tej sprawy „dochodzenie do pracy”, nie przesądza o braku przesłanki deportacji w rozumieniu art. 2 pkt 2 ustawy. Dla ustalenia istnienia tej przesłanki istotne są bowiem wszystkie okoliczności sprawy, które w stanie faktycznym konkretnej sprawy mogą przesądzić o uznaniu za deportację również wywiezienia do pracy przymusowej do miejscowości położonej w niewielkiej odległości od dotychczasowego miejsca zamieszkania. Należy mieć bowiem na uwadze to, że do pracy przymusowej, jak w tej sprawie - wywożone były dzieci, dla których zmiana miejsca pobytu, nawet jeśli miejsce to nie było znacznie oddalone od dotychczasowego miejsca zamieszkania, w powiązaniu z innymi czynnikami, może przesądzać o zaostrzonym charakterze represji, której zostały poddane. W tym też kontekście istotne jest zatem ustalenie nie tylko samej odległości od dotychczasowego miejsca zamieszkania do miejscowości, do której dana osoba została wywieziona, ale również, gdzie przebywała jej najbliższa rodzina, czy mogła się z nią kontaktować, w jakich warunkach żyła po wywiezieniu do pracy przymusowej, jakiego rodzaju pracę wykonywała, jakie było wobec niej nastawienie nowego otoczenia. Wszystkie te czynniki łącznie mogą bowiem w okolicznościach konkretnej sprawy przesądzić o zaistnieniu przesłanki deportacji w przedstawionym wyżej rozumieniu.

Skarżący w toku postępowania podnosił, że pracę przymusową wykonywał codziennie od rana do późnych godzin wieczornych. Odległość, jaką dziennie musiało pokonać dziecko do i z pracy to $32 \mathrm{~km}$, czyli tyle, ile dziennie pokonują pielgrzymi jednej z najdłuższych w Polsce tras pielgrzymek na J.G. do C. (ze Ś . i S.). Pokonywana dziennie odległość w połączeniu z niewolniczą pracą nie dają możliwości obrony tezy o podtrzymaniu normalnych czy wręcz jakichkolwiek relacji społecznych i rodzinnych. Jeśli przyjąć, że przeciętnie dorosły człowiek maszeruje z prędkością $5 \mathrm{~km} / \mathrm{h}$, to na pokonanie trasy, jaką miał Skarżący potrzebowałby dziennie 6 godzin (gdyby był dorosłym, w miarę szybko maszerującym człowiekiem). Uwzględnienie, że Skarżący był dzieckiem oraz proste zestawienie czasu, który Skarżący musiał poświęcić na dojście do i z pracy i czasu samej pracy wykonywanej od rana do wieczora, dałoby Organowi obraz rzeczywistości dziecka i czasu, jaki mógł „spędzić z rodziną”, przy odliczeniu oczywiście czasu możliwego do wykorzystania na sen.

12. Biorąc powyższe pod uwagę, w ocenie Sądu Skarżący, nawet jeśli wracał wyczerpany, głodny i spragniony do rodzinnego domu, to wbrew bezrefleksyjnemu stanowisku Organu, nie miał możliwości utrzymywania rodzinnych i społecznych relacji, jakie w tym wieku powinno utrzymywać dziecko. Ponadto Skarżący 
podnosił, że powrót do domu stanowił przepustkę/nagrodę, zatem oświadczenie to powinno raczej skutkować przyjęciem, że co do zasady nie było to dozwolone. Organ nie ocenił prawidłowo powyższej okoliczności, szczególnie w kontekście młodego wieku Skarżącego, faktu wykonywania pracy od świtu do zmroku, a także faktu zaostrzenia represji w stosunku do Skarżącego i doznanej przez niego w wyniku pobicia przez Niemca utraty wzroku w jednym oku. Wszystkie wskazane okoliczności oznaczać powinny, że Skarżący został wyrwany ze swojego dotychczasowego środowiska, pozbawiony więzi rodzinnych, przyjacielskich i sąsiedzkich, poddany represjom oraz zmuszony do niewolniczej pracy

Powyższe okoliczności świadczą niewątpliwie o represji w stosunku do Skarżącego, co wskazywać może na zaistnienie w jego przepadku przesłanek deportacji w rozumieniu art. 2 pkt 2 ustawy, a w konsekwencji mogły stać się podstawą do przyznania Skarżącemu wnioskowanego świadczenia pieniężnego. Jednak okoliczności te nie zostały zinterpretowane i ocenione w prawidłowy sposób przez organ rozpatrujący sprawę, ani rozważone zgodnie $\mathrm{z}$ art. 80 K.p.a.

Wskazać trzeba, że ustalenie stanu faktycznego w drodze wyczerpującego zebrania i oceny materiału dowodowego jest funkcją postępowania administracyjnego. W postępowaniu administracyjnym to organy administracji publicznej zobowiązane są, zgodnie z art. 7 i $77 \$ 1$ K.p.a., do podejmowania wszelkich kroków niezbędnych do dokładnego wyjaśnienia stanu faktycznego oraz wyczerpującego zebrania i rozpatrzenia całego materiału dowodowego, mając na względzie interes społeczny i słuszny interes obywateli. Na nich zatem spoczywa obowiązek przeprowadzenia całego postępowania, co do wszystkich istotnych okoliczności rozpoznawanej sprawy, a także oceny na podstawie całokształtu materiału dowodowego czy dana okoliczność została udowodniona.

13. Z lektury akt sprawy wynika, że Organ nie zadał sobie trudu przeanalizowania treści zawartych w składanych przez Skarżącego pismach. O znacznej nieporadności Skarżącego w formułowaniu myśli świadczy jego wniosek, gdyż wyraźnie widać, że samo pisanie sprawia mu kłopot (zdołał się ledwo podpisać). W tej sytuacji Organ powinien rzetelnie zebrać informacje od Skarżącego w dogodnych dla niego warunkach, w sposób uwzględniający jego sytuację, zwłaszcza zdrowotną (na piśmie bądź w drodze przesłuchania w miejscu zamieszkania), tak by uzyskać informacje co do wywiezienia do pracy przymusowej; możliwości opuszczania miejsca wywiezienia, warunków nie tylko pracy ale i życia, czy było przyzwolenie na rozmawianie w języku polskim, zachowania Niemców wobec Skarżącego, charakteru możliwości powrotu do domu rodzinnego itp. Dopiero tak zebrany materiał dowodowy (wszystko to, co podał Skarżący w swoich pismach do Organu, ew. wskazane przesłuchanie dokonane we właściwy sposób, zeznania świadka wnioskowanego 
przez Skarżącego, dałoby podstawy do dokonania przez Organ rozpatrzenia i rozstrzygnięcia sprawy).

Stwierdzić zatem należy, że Organ nie przeprowadził w sposób należyty postępowania dowodowego, $z$ naruszeniem przepisów art. 7 , art. $77 \$ 1$ i nie rozpatrzył ich zgodnie z wymogami art. 80 K.p.a. W konsekwencji Organ dopuścił się również naruszenia art. $107 \$ 1$ i 3 K.p.a., który wymaga, by uzasadnienie faktyczne decyzji zawierało wskazanie faktów, które organ uznał za udowodnione, dowodów, na których się oparł, oraz przyczyn z powodu których innym dowodom odmówił wiarygodności i mocy dowodowej, zaś uzasadnienie prawne, wyjaśnienie podstawy prawnej decyzji z przytoczeniem przepisów prawa.

14. Końcowo Sąd zauważa, że z lektury uzasadnień obu decyzji odnieść można wrażenie, że Organ, mimo że jest powołany do rozstrzygania spraw ludzi starszych $\mathrm{z}$ reguły pokrzywdzonych w czasie okupacji hitlerowskiej, nie skupił się na wszechstronnym i rzetelnym zebraniu dowodów, ich właściwej swobodnej ocenie i wyważonym rozstrzygnięciu, lecz dążył przede wszystkim do uzasadnienia decyzji negatywnej, odmawiającej świadczenia. Takie podejście Organu nie zasługuje na aprobatę.

15. Przy ponownym rozpoznawaniu sprawy i podejmowaniu rozstrzygnięcia Organ powinien uwzględnić poczynione wyżej uwagi. Zgodnie bowiem $\mathrm{z}$ treścią art. 153 ustawy - Prawo o postępowaniu przed sądami administracyjnymi ocena prawna i wskazania co do dalszego postępowania wyrażone w orzeczeniu sądu wiążą w sprawie ten sąd oraz organ, którego działanie lub bezczynność było przedmiotem zaskarżenia. Organ przeprowadzi też dokładne i wyczerpujące postępowanie dowodowe, uwzględniając zasadę szybkości postępowania i biorąc pod uwagę podeszły wiek Skarżącego, by nie przedłużać zbędnie procedowania, w konsekwencji którego rozstrzygnie o uprawnieniu Skarżącego do dochodzonego świadczenia. Następnie wyda decyzję, zawierającą uzasadnienie zgodne z przepisem art. $107 \$ 3$ K.p.a.

16. Biorąc powyższe pod uwagę Sąd, na podstawie art. $145 \$ 1$ pkt 1 lit. a i c w związku z art. 135 ustawy - Prawo o postępowaniu przed sądami administracyjnymi, z uwagi na naruszenie prawa materialnego - przez jego błędną wykładnię oraz naruszenie prawa procesowego, które mogło mieć istotny wpływ na wynik sprawy, uchylił zaskarżoną decyzję oraz decyzję ją poprzedzającą. 